are described in detail. These consist of round and oval carities and bodies, the largest of which are about 6 millimetres in greatest width. Nothing can be proved regarding their origin, but the description of the rocks is summarized and a hypothesis adopted regarding their history, as follows :-

(1) The tourmaline-corundum rocks of Kinta consist of varying amounts of tourmaline, corundum, carbon, white mica, spinel, and other minerals.

(2) They contain cavities about 6 millimetres in greatest width, generally bordered by a laser of corundum grains, with tourmaline grains on the inside of this border. Sometimes solid bodies similar in size and shape to the cavities occur. They are composed of tourmaline and corundum, the former mineral, generally speaking, being more abundant towards the centre. Such bodies also show concentric structure.

(3) Smaller bodies occur, sometimes, but not always, accompanied by the larger carities and bodies. They consist of tourmaline, of corundum, and of tourmaline and corundum. When both minerals are present, the corundum forms a shell to a nucleus of tourmaline. The corundum bodies frequently show concentric structure.

(4) The tourmaline-corundum rocks are associated with other rocks, which lead to the conclusion that the structures described in (2) and (3) are the result of replacement of the materials of pre-existing bodies at the time of extensive granitic intrusions.

(5) They also are associated with rocks which point to the original beds having been laid down under conditions similar to those that obtained when the Pahang Chert Series was deposited.

(6) As tourmaline-bearing partings in the limestone at Changkat Pari constitute a case of selective metamorphism, so it is thought that the tourmaline-corundum rocks as a whole mark a process of selective and intense metamorphism in beds associated with schists overlying the Kinta Limestone.

(7) These beds were probably chert and silicified limestone, both being in many cases carbonaceous.

(8) The larger cavities and bodies mentioned in (2) are believed to be the result of replacement or partial replacement of oolitic grains.

(9) The smaller bodies mas be, in part, the result of replacement of the materials forming casts of radiolarian structures; in part, the result of the further development or replacement of spots seen in soft partings in the limestone at Changkat Pari; and in part, the result of the replacement of small oolitic grains.

O円ITUARY.

\title{
HILARY BAUERMAN,
}

Assoc.M.Inst. C.E., Assoc. R.S.M., F.G.S.

BorN 1833.

Died December 5, 1909.

The closing days of the old year have gathered in another prominent geologist and fellow-worker to his well-earned rest, leaving our science the poorer, and ourselves to regret his loss. Of Hilary Bauerman's 
early days we are not informed, but in 1851 , at the age of 18 , he became a student at "the Government School of Mines and of Science applied to the Arts", Jermyn Street, where he had the advantage of studying under Playfair, Ramsay, Forbes, Warington Smyth, Hunt, and Percy. It was specially due to the personal influence exercised by Dr. Percy and Sir Warington Smyth over the early students of the school that so many high classmen, like Bauerman, the Blanfords, F. Drew, Tookey, sir C. Le Neve Foster, and many others, went forth to achieve high geological distinction in the world. From Jermyn Street Bauerman proceeded, in 1853, to the Freiberg Mining. Academy, whence, after three years further study, he returned to England, and in 1856 accepted the post of an Assistant Geologist on the Geological Survey of Great Britain. But after three years work at home he was selected as geologist to the North American Boundars Commission, and during nearly six years he was occupied in most arduous survey work in Canada and the United States, including the delimitation of the Hudson Bay territors. Between 1863 and 1888 he was busily engaged in Government and professional work, mining and metallurgical surveys, and explorations abroad in almost every part of the world, save Australia and New Zealand. In 1883 he was appointed lecturer on metallurgy at Firth College, Sheffield, and still earlier (1874-9) was joint examiner in mining and mineralogy for the Science and Art Department.

His last official appointment (in 1886) was that of Professor of Metallurgy to the Ordnance College, Woolwich, from which he only retired in 1906, after some twenty years service. As a teacher, Professor Bauerman was particularly successful both with the cadets at Woolwich, who admired and revered him, and with the practical miners and metallurgists, including his workmen-students at the Firth College, Sheffield, and elsewhere, many of whom afterwards became his personal friends.

In addition to important papers read before learned and technical societies Professor Bauerman was the author of textbooks on Descriptive Mineralogy and on Systematic Mineralogy. But his name is best known perhaps in connexion with his classical work on the Metallurgy of Iron, and with the treatise on Metallurgy by Phillips \& Bauerman. He was for many years a ralued contributor to the columns of the Engineer, the Mining Journal, and other papers.

His extensive knowledge of chemical, mineralogical, and metallurgical subjects, and his experience as a teacher, led to his selection for the office of examiner for many years to the Civil Service Commissioners for the appointment of Mine Inspectors, to the Science and Art Department and the Board of Education in mining and metallurgy, and for a time in mineralogy also. He was likewise examiner of mining students to the Royal School of Mines and the Camborne School of Mines.

Few of the congresses at home or abroad passed without his presence. He was a member of the Metallurgical Committee of the Seventh International Congress of Applied Chemistry held in London this year, and president of a section of the Sixth Congress held in Rome, 1906 ; and most of our International Exhibitions had the benefit 
of his experience as counsellor or juryman, from the Great Exhibition in 1851 to the Franco-British in 1908, on whose metallurgical section he wrote two excellent monographs, published by the Iron and Steel Institute.

Mr. Bauerman was elected a Fellow in 1863, and for nearly twenty years served on the Council of the Geological Society (from 1874 to 1898); he also filled the office of Vice-President. He was a most valuable referee on all scientific papers, and, like the late Professor Morris, his knowledge was encyclopæedic both of men and subjects.

Bauerman's information was by no means confined to his own particular subjects, but extended over many sciences and arts. His interest in crystallography became an absorbing pursuit; and he found no greater delight than, with no appliances beyond an old envelope, picked out of the waste-paper basket, he would simply by deft folding, accompanied always by constant puffing and blowing, and many a joyful chuckle, develop some extraordinary figure in solid geometry.

Professor Bauerman was a member of many scientific societies both at home and abroad. He was elected an honorary member of the Chemical, the Metallurgical, the Institute of Mining and Metallurgy, and the Iron and Steel Institute. He was an associate member of the Institution of Civil Engineers, as an F.G.S. he for many years filled the office of Treasurer to the Geological Club, and was an associate of the Royal School of Mines. He received the Howard Prize from the Institution of Civil Engineers in 1897, and in 1906 was awarded the gold medal of the Institute of Mining and Metallurgy.

He was a perfect master of three languages, and being of an amiable disposition he always proved a most agreeable and interesting travelling companion, full of keen humour and geniality, so that throughout his life he attracted a large circle of warmly attached and admiring friends.

Professor Bauerman had been seriously ill for about ten weeks, but the immediate cause of his death, which took place peacefully on the morning of December 5, was heart failure. (See notices in the Engineer, the Mining Journal, Iron and Steel Institute, and Nature.)

\section{MISCEIIANEOUS.}

Mr. O. T. Jones, M.A., B.Sc., of the Geological Survey of England and Wales, has been appointed Lecturer in Geology and Physical Geography in University College, Aberystwyth.

Mr. H. J. Sermodr, B.A., of the Geological Survey of Ireland, has been appointed Professor of Geology in University College, Dublin.

Museum Destroxed by Fire.-The public library and museum at Kilmamock has been destroyed by fire. The building, known as the Dick Institute, was presented to the town by the late Mr. James Dick, of Glasgow, about nine years ago. The museum contained the geological collection of the late Mr. James Thompson, F.G.S., the destruction of which is much to be deplored.-Times (weekly ed.), December 3, 1909. 